\title{
NATURAL PRODUCTS EFFECT OF TREATMENTS ON GENE TARGETING METABOLISM ON BREAST CANCER
}

\author{
Salwa E. Mohamed ${ }^{1}$, Midaa N. Ashry ${ }^{2}$, Khalil Halfawy ${ }^{3}$, Wael H.Roshdy ${ }^{4}$, \\ and Wael S. Abdel-Mageed ${ }^{5}$ \\ 1 Molecular Cell Biology \& Molecular Biology Department, Genetic \\ Engineering and Biotechnoloy Research Institute,(GEBRI)University of Sadat \\ City, Egypt. \\ 2 Medical Laboratories Department, Faculty of Applied Medical Sciences, \\ October 6 University, Egypt. \\ ${ }^{3}$ Molecular Genatics and Molecular biology Department, Genetic engineering \\ and Biotechnology Research Institute, Sadat City University, Egypt. \\ 4 Central Public Health Laboratories, Ministry of Health and Population, \\ Cairo, Egypt. \\ ${ }^{5}$ Genetics Department, Faculty of Agriculture, Beni-Suif University, Egypt.
}

\section{ABSTRACT}

Breast cancer is among the most common malignant tumors. It is the second leading cause of cancer deaths among women. While mutation in the BRCA1 and BRCA2 genes confer risk of developing breast cancer. Insulin-like growth factors (IGFs) IGF-1 and IGF-2 are associated with the development and progression of breast cancer. Curcumin is a polyphenol natural product isolated from the rhizome of Curcuma longa. For centuries, curcumin has been used in medicinal preparations and as a food colorant. In recent years, Curcumin, has been reported to have anticancer and chemoprevention effects on breast cancer. Particularly, curcumin has been recognized as an effective anticancer agent that regulates multiple intracellular signaling pathways. This study is designed to investigate the effect of curcumin on gene targeting metabolism on breast cancer.

To achieve this aim we conducted the study on MCF-7 cell lines, and evaluate the cytotoxicity of different concentration of curcumin by MTT assay, RNA extracted from MCF-7 cell lines by Qiagen method and reverse transcriptase to $c D N A$ finally quantification of the expression of genes (IGF-1, IGF-2 and BRCA1) by Real time PCR (RT-PCR).

The results showed that different concentration of curcumin make inactivation for genes related to breast cancer (IGF1, IGF2 and BRCA1) and can stop the breast cancer pathway. 
Conclusively, breast cancer is among the most common malignant tumors. It is the second leading cause of cancer mortality among women in the world. Curcumin, an active derivative from turmeric, has been investigated to have anticancer and chemoprevention effects on breast cancer.in this study different concentrations of curcumin influence the expression of gene targeting metabolism on breast cancer and make inactivation to it which may lead to stopping the breast cancer pathway. Our data demonstrated that curcumin could be used as the treatment of breast cancer.

Keywords: Breast cancer, IGFs genes, BRCA genes, Curcumin.

\section{INTRODUCTION}

Cancer is not just one disease, but a large group of almost 100 diseases. It has become one of the top causes of morbidity and mortality, with approximately19.3 a million new cases and about10.0 a million deaths in 2018 based on the Global Cancer (GLOBOCAN 2020) (Sung et al., 2021). In other words, cancer is responsible for nearly one of the six deaths, leading to its recognition as one of the world's most prominent "killers" (Stewart et al., 2016). In addition to that, The global cancer burden is expected to be 28.4 million cases in 2040, a $47 \%$ rise from 2020, with a larger increase in transitioning (64\% to $95 \%$ ) versus transitioned (32\% to $56 \%$ ) countries due to demographic changes, although this may be further exacerbated by increasing risk factors associated with globalization and a growing economy (Sung et al., 2021).

As the leading malignancy in females, Breast cancer is the most commonly diagnosed cancer among women worldwide (Ferlay et al., 2015). There are several recognized risk factors for breast cancer development including hormonal, reproductive, and menstrual history, age, lack of exercise, alcohol, radiation, benign breast disease, and obesity. Nevertheless, the key factor to breast cancer development is the early onset of disease (Yang et al., 2011). Risk factors for breast cancer include early menarche, late menopause, nulliparity, contraceptive use, hormonal replacement therapy, above-average body mass index, exposure to environmental pollutants, smoking, use of alcohol and family history (Lambrechts et al., 2011).

The main cause of breast cancer is related with a personal or family history of the disease and inherited genetic mutations in the breast cancer susceptibility genes BRCA1 and BRCA2. BRCA1 and BRCA2 are two of the most important breast cancer susceptibility genes (Tinelli et al., 2010). The 
BRCA genes play a critical role in cell damage repair and induce cell death to those cells if the damage is beyond rescue. BRCA mutation leads to abnormal breast tissue proliferation and increases breast cancer risk (Downs and Wang, 2015).

Insulin-like growth factors (IGFs) are associated with the development and progression of breast cancer. IGF-1 and IGF-2 transmit their signals through two paralogous receptor proteins located in the plasma membrane: the type 1 IGF receptor and the insulin receptor (IGF receptors). High circulating IGF-1 concentrations and low blood IGF binding protein concentrations are risk factors for several types of cancer including breast cancer (Schernhammer et al., 2005 and Renehan et al., 2006). Some studies indicate that IGF-2 activates ER-a and ER-b and modulates their translocation to the nucleus, membrane organelles and the mitochondria (Richardson et al., 2011). The IGFs and IGF-IR function to promote proliferation inhibit death and stimulate transformation in breast cancer cells. Besides their mitogenic ability, IGFs also mediates several other responses. IGFs protect breast cancer cells from apoptosis and promote survival (Rubin and Baserga, 1995). IGFs provide radioprotection and resistance of breast cancer cells to chemotherapeutic agents (Gooch et al., 1999).

No single treatment for cancer seems possible. Patients are often given a combination of therapies and palliative care,such as surgery, radiation, immunotherapy, chemotherapy, or gene therapy, depending on the type and stage of cancer and the patient's health status, age, and personal characteristics(Gupta et al., 2013a).

Curcumin is the main active ingredient in the rhizome of turmeric (Curcuma longa). Curcumin has a variety of therapeutic properties including antioxidant, analgesic, anti-inflammatory, antiseptic activity, and anti-carcinogenic activity (Perrone et al., 2015) . Curcumin is generally recognized as safe by the FDA. Curcumin was known to be safe for human consumption up to $12 \mathrm{~g}$ /day during clinical trials without recording any side effects (Gupta et al., 2013b). However, some studies indicated that high concentrations of curcumin affected directly on the genetic material in the nucleus as well mitochondrial DNA in cancer cell lines (Cao et al., 2006) . To overcome the drawbacks of bioavailability and rapid metabolism of curcumin, efforts were achieved to develop novel synthetic curcumin formulations( Toden and Goel, 2017).

Curcumin is a hydrophobic polyphenol derived from turmeric,a traditional Indian spice. Curcumin has been used as an ethnic drug for the treatment of diverse diseases. Particularly, curcumin has been recognized as an effective anticancer agent that regulates multiple intracellular signaling 
pathways (Singletary et al., 1996). Curcumin is known as a yellow pigment that is extracted from Curcuma longa (Mirzaei et al., 2017) . Multiple lines of evidence indicated that curcumin and its analogs show a range of pharmacological properties such as anti-cancer, anti-inflammation, and antioxidant (Mirzaei et al., 2017). Among of these properties, anti-cancer effects of curcumin are known as one of the important effects of it. It has been shown that curcumin could exert their anti-cancer properties via inhibition of angiogenesis, cell proliferation, metastasis, and invasion (Zhou et al., 2017) .Moreover, curcumin could induce apoptosis in cancer cell line, regulation of cell cycle, and increase of chemotherapy sensitivity (Zhou et al., 2017) . Several mechanisms have been proposed to account for the action of curcumin in breast cancer cells. Several reports have described the anticarcinogenic activity of curcumin in a variety of breast cancer cell lines. One study established that the antiproliferative effect of curcumin in human breast cancer cell lines, including hormone-dependent, hormone-independent, and multidrugresistant cells, was time- and dose-dependent, and correlated with curcumin's inhibition of the ornithine decarboxylase activity (Aggarwal et al., 2006). The focus of this short review is to describe effect of curcumin in the regulation of gene expression in breast cancer.

Therefore, this study aimed to evaluate the molecular effect of curcumin on gene targeting energy metabolism of breast cancer.

\section{MATERIALS \&METHODS}

\section{Chemicals}

Dulbecco's modified Eagle's medium (DMEM), fetal bovine serum (FBS),Trypsin-EDTA (1x) and antibiotic solution (penicillin and streptomycin), and phosphate-buffered saline (PBS) ,3-(4,5-Dimethylthiazol-2-yl)-2,5diphenyltetrazoliumbromide (MTT), propidium iodide and dimethyl sulfoxid (DMSO) .All chemicals were obtained from Central Public Health Laboratories in Egypt (CPHL). Primers were obtained from (Applied Biosystems), RNA extraction kit obtained from (Qiagen, Hilden, Germany) and PCR kit HERA SYBER GREEN/ROX RT-qPCR obtained from (Applied Biosystems, Foster City, California, USA). All work was done in the Central Public Health Laboratories in Egypt (CPHL).

\section{Preparation of Curcumin}

Curcuma longa (Turmeric) root were selected based on their ethnomedical importance. Healthy disease-free roots were purchased from local market in Egypt. The plant materials were dried and pulverized. A weight of 40 
mg of well air-dried powder of Curcuma longa roots was infused in aqueous solution $(100 \mathrm{ml})$ until complete exhaustion. The infusion was filtered through four-layered muslin cloth. Total concentration of obtained extract was $40 \mathrm{mg} / \mathrm{L}$ that was stored at $4^{\circ} \mathrm{C}$ till further use.

\section{Cell line and cell culture}

Human breast cancer cell line, MCF7, was obtained from central public health laboratories in Egypt (CPHL). The cells were cultivated in T75 tissue culture flasks in low glucose Dulbecco's modified Eagle's medium (DMEM) supplemented with $10 \%$ fetal bovine serum, $100 \mu \mathrm{g} / \mathrm{mL}$ penicillin, $100 \mu \mathrm{g} / \mathrm{mL}$ streptomycin, $2 \mathrm{mM} / \mathrm{L}$-glutamine and incubated in a 95\%humidified incubator containing $5 \% \mathrm{CO} 2$ at $37^{\circ} \mathrm{C}$. Now cells ready for treatment with curcumin.

\section{Cytotoxicity}

To evaluate the cell viability and cell cytotoxicity was assessed using the 3-(4, 5-dimethylthiazol -2-yl)-2, 5-diphenyltetrazolium bromide (MTT) assay (Mossman, 1983). Briefly, cells were seeded in 96-well plates in DMEM supplemented with $10 \%$ fetal bovine serum, and $1 \%$ antibiotic antimycotic mixture. After $24 \mathrm{~h}$ of cell preparation, the growth medium was aspirated from each well and the cells washed with $1 \mathrm{X}$ phosphate buffered saline (PBS). Different concentrations of curcumin were two fold serially diluted in DMEM then added to cultured cells in 96-well plate in triplicate and incubated for $24 \mathrm{~h}$ post treatment to determine the cytotoxic concentration 50 (CC50). The medium was then removed and the monolayer of cells washed with $1 \mathrm{X}$ PBS three times before adding MTT solution ( $20 \mu \mathrm{L} /$ well of $5 \mathrm{mg} / \mathrm{ml}$ stock solution) and incubated at $37{ }^{\circ} \mathrm{C}$ for $4 \mathrm{~h}$ till formulation of formazan crystals. Crystals were dissolved using a volume of $200 \mu \mathrm{L}$ of of acidified isopropanol and the absorbance measured at $\lambda \max 540 \mathrm{~nm}$ using an ELISA microplate reader. Finally, the percentage of cytotoxicity compared to the untreated cells was determined. The CC50 of curcumin was determined from a linear exponential equation:

\% Cytotoxicity $=($ Absorbance of cell without treatment - Absorbance of cell with treatment) / Absorbance of cell without treatment X100

\section{Real-time polymerase chain reaction with SYBR green:}

Total RNA was extracted from cells using RNeasy Mini Kit (Qiagen) extraction kit according to the manufacturer's protocol (Qiagen, Hilden, Germany). Subsequently, Five hundred nanograms of the purified RNA were used to synthesize the complementary DNA(cDNA) with Reverse 
Transcriptase according to the manufacturer's protocol(HERA SYBR® green RT-qPCR kit). The quantitative real-time PCR (qRT-PCR) according to the manufacturer's protocol (HERA SYBR green RT-qPCR kit).reaction mixture (20 $\mu$ l) comprises the following: $2.0 \mu$ of RNA template, $1.0 \mu \mathrm{l}$ of RT Enzyme Mix, 1.0 $\mu$ l HERA RT-qPCR Master Mix (Thermo Scientific) and $1.0 \mu \mathrm{l}$ of each primer (100 $\mu \mathrm{M}$ forward and reverse primers) Until $20 \mu \mathrm{l}$ Nuclease free water. Reactions were run in triplicate on Applied Biosystems 7500 real-time PCR system (Applied Biosystems, Foster City, California, USA). The cycling conditions were as follows: Stage 1 (Reverse Transcription) $15 \mathrm{~min}$ at $50{ }^{\circ} \mathrm{C}$, Stage 2 ( Enz. Activation) $5 \mathrm{~min}$ at $95{ }^{\circ} \mathrm{C}$,Stage 3.1 ( Denaturation ) $10 \mathrm{~s}$ at 95 ${ }^{\circ} \mathrm{C}$, Stage 3.2 ( Annealing/Extention ) $30 \mathrm{~s}$ at $60{ }^{\circ} \mathrm{C}$, DNA were amplified by 50 cycles of PCR. The primer sequences were as follows: for IGF1 forward primer, (5'-CTTGGACTTTGAGTCAAATTGG $\mathbf{- 3}^{\prime}$ ), IGF1 reverse primer, (5'GTTCGTGCCAATTACATTTCA $\quad \mathbf{3}^{\prime}$ ); IGF2 forward primer, $\quad \mathbf{5}^{\prime}$ TCCTGGAGACGTACTGTGCTA $\mathbf{- 3}^{\prime}$ ),IGF2 reverse primer,(5'CCTCCTTTGGTCTTACTGGG $\mathbf{- 3}^{\prime}$ ); BRACA1 Forward primer, (5' GGACGITGTCAITAGITCTITGG $\mathbf{- 3}^{\prime}$ ), BRACA1 reverse primer, $\quad \mathbf{5}^{\prime}$ TTGCATAGGAGATAATCATAGGAA $\mathbf{- 3}^{\prime}$ ) and for $\beta$ actin, forward (5CACCATTGGCAATGAGCGGTTC -3) and reverse (5AGGTCTTTGCGGATGTCCACGT -3).(NM_001101). Ct values were normalized to the values of the control $\beta$-actin house-keeping transcripts and $\log$ fold change was calculated according to the equation of $2^{\wedge}-\Delta \Delta$ ct (Rao et al., 2013).

\section{Statistical evaluation}

Statistical analysis: Results are expressed as mean \pm S.E and values of $\mathrm{P}>0.05$ were not considered significantly different, whereas values of $\mathrm{P}<0.05$ and $\mathrm{P}<0.01$ were considered significant and highly significant respectively. The one-way ANOVA test was used for statistical analysis, followed by Bonferroni's Multiple Comparison test. (Roa et al., 1985).A value of $\mathrm{P}<0.05$ was considered as statistically significant. For all statistical tools; the threshold of significance was fixed at the 0.05 level.

\section{RESULTS AND DISCUSSION}

Curcumin has been found to suppress carcinogenesis of the breast and other organs. Using curcumin as a therapeutic and preventive agent in breast cancer is perplexed by its diverse biological activity, much of which remains inexplicable (Wang et al., 2016). Breast cancer is considered the most common 
cancer for women worldwide and it is now the second leading cause of cancerrelated deaths among females in the world. Since breast cancer is highly resistant to chemotherapy, alternative anticancer strategies have been developed. In particular, many studies have demonstrated that curcumin, a derivative of turmeric, can be used as natural agent in treatment of some types of cancer by playing anti-proliferative and antioxidant effects (Bimonte et al., 2015).

\section{Cytotoxicity of cur cumin extract on MCF-7 cell line:}

The cytotoxicity of the curcumin extract was evaluated in MCF-7 cell line using MTT assay. The curcumin was almost not toxic for studied cells up to a dose of $64 \mu \mathrm{g} / \mu \mathrm{l}$ (Fig.1). The toxic effect of tested extract was dosedependent. The result showed that the cytotoxic concentration 50 (CC50) value of curcumin was $64 \mu \mathrm{g} / \mu \mathrm{l}$. Therefore, for further studies we selected the safe concentrations of $25 \mu \mathrm{g} / \mu \mathrm{l}$ and $50 \mu \mathrm{g} / \mu \mathrm{l}$ for subsequent cellular signal studies.

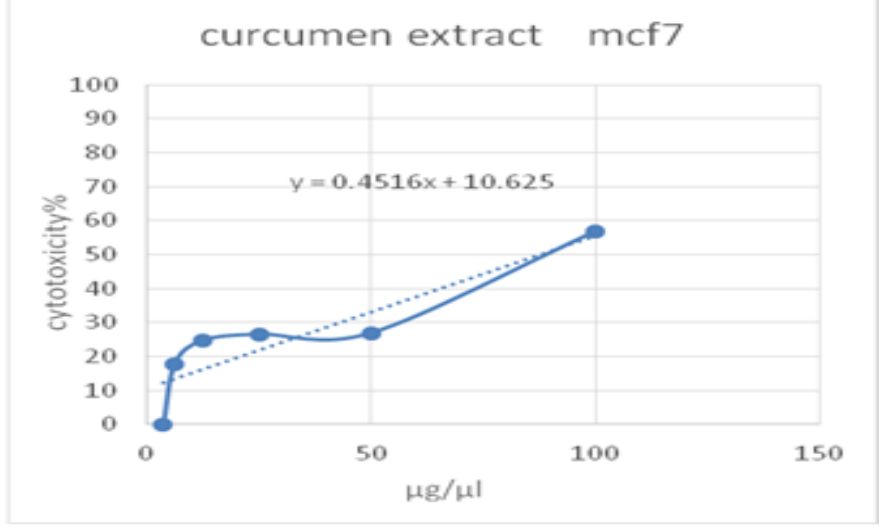

Figure .1: The cytotoxicity Effect of the curcumin on the viability of MCF-7 cell lines treated and measured by MTT assay. TC50 $=\mathbf{6 4} \boldsymbol{\mu \mathrm { g }} / \boldsymbol{\mu \mathrm { l }}$.

\section{Molecular evaluation for gene expression by real time PCR:}

These findings revealed the effects of the different concentration of curcumin $(25-50 \mu \mathrm{g} / \mu \mathrm{l})$ on the different genes like (IGF-1-IGF-2 and BRCA-1) in breast cancer on MCF-7 cell line. which the figures show the log fold change of gene and the different duration time $(0 \mathrm{~h}, 8 \mathrm{~h}, 16 \mathrm{~h}, 24 \mathrm{~h}, 32 \mathrm{~h}, 40 \mathrm{~h}, 48 \mathrm{~h}, 56 \mathrm{~h}$, $64 \mathrm{~h}$ and $72 \mathrm{~h}$ ), the figures expressed the significant and non-significant, the comparison between each hour to the first 8hour and comparison between each gene and the different concentration of curcumin $(25-50 \mu \mathrm{g} / \mu \mathrm{l})$.This molecular evaluation for gene expression was measured by Real Time PCR. 
Table 1: Effect of concentration of curcumin $(25-50 \mu \mathrm{g} / \mu \mathrm{l})$ on IGF-1 gene

\begin{tabular}{|l|l|l|}
\hline \multicolumn{3}{|c|}{ Concentration of curcumin $(25 \mu \mathrm{g} / \mu \mathrm{I})$ and $(50 \mu \mathrm{g} / \mu \mathrm{I})$ on IGF-1 gene } \\
\hline Hours & $\begin{array}{l}\text { IGF-1 } \\
\text { At }(25 \mu \mathrm{g} / \mu \mathrm{I}) \text { curcumin }\end{array}$ & $\begin{array}{l}\text { IGF-1 } \\
\text { At }(50 \mu \mathrm{g} / \mu \mathrm{I}) \text { curcumin }\end{array}$ \\
\hline 0 & 0 & 0 \\
\hline 8 & $-0.48 \pm 0.17^{*}$ & $-0.67 \pm 0.24^{*}$ \\
\hline 16 & $-0.53 \pm 0.12^{*}$ & $-1.45 \pm 0.53^{*}$ \\
\hline 24 & $-1.02 \pm 0.3^{*}$ & $-1.22 \pm 0.30^{*}$ \\
\hline 32 & $-1.38 \pm 0.7^{*}$ & $-0.66 \pm 0.25^{*}$ \\
\hline 40 & $-1.83 \pm 1.1^{*}$ & $-1.26 \pm 0.34^{*}$ \\
\hline 48 & $-1.41 \pm 0.7^{*}$ & $-1.44 \pm 0.52^{*}$ \\
\hline 56 & $-2.58 \pm 1.9^{*}$ & $-2.3 \pm 1.3^{*}$ \\
\hline 64 & $-2.82 \pm 2.1^{* *}$ & $-3.37 \pm 2.4^{* *}$ \\
\hline 72 & $-3.07 \pm 2.4^{* *}$ & $-3.4 \pm 2.5^{* *}$ \\
\hline
\end{tabular}

*Significant at p-value $<0.05$

$* *$ Highly Significant at p-value $<0.001$

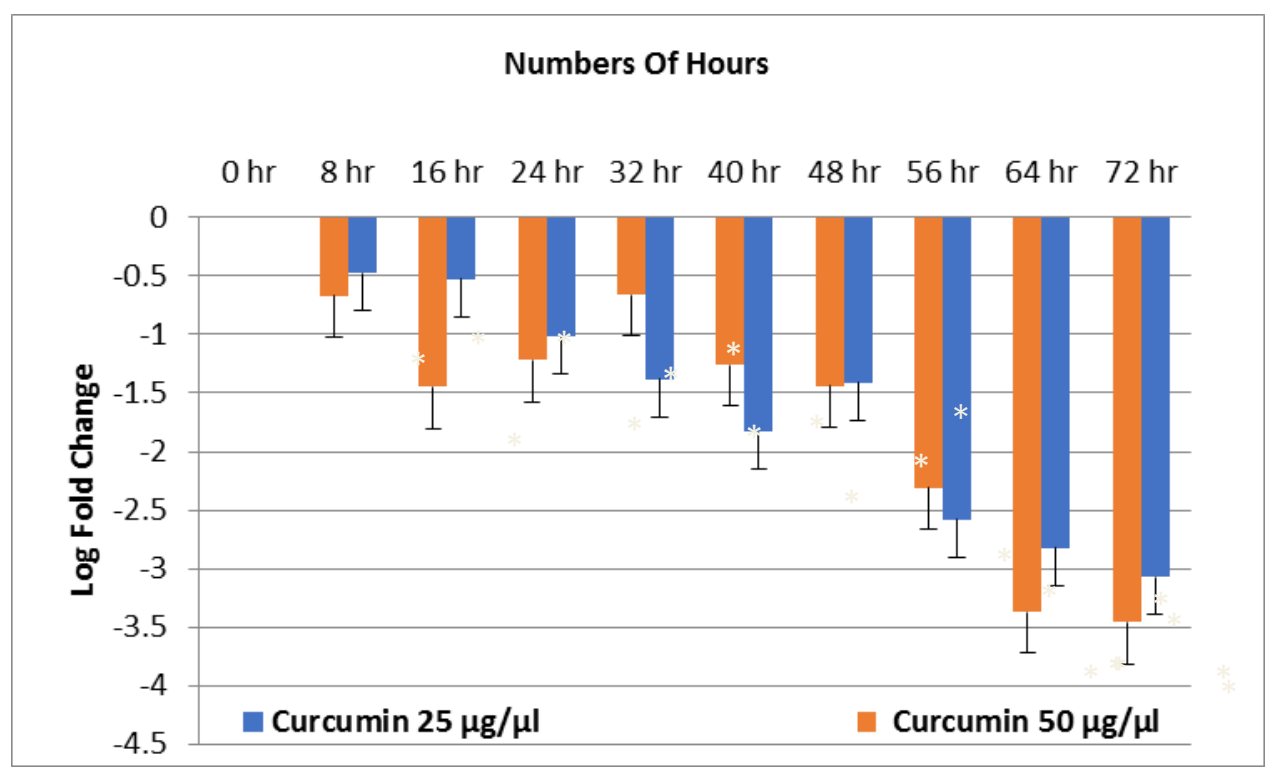

Figure 2: Multiple comparisons between the value of different concentrations of Curcumin $(25-50 \mu \mathrm{g} / \mu \mathrm{l})$ in IGF-1. Data represent the mean \pm standard error. The signs $(* * P<0.01, * P<0.05)$ denote significant differences from control and other treatment groups.

The effect of curcumin concentration $(25-50 \mu \mathrm{g} / \mu \mathrm{l})$ on IGF-1 gene was highly statistically significant changed between (72 and 64 hours) and ( 8 hours).The 
dose response as indicated in (Figure 2 and Table 1) and The effect of curcumin concentration $(25 \mu \mathrm{g} / \mu \mathrm{l})$ on IGF-2 gene was highly statistically significant changed between ( 72 hours) and ( 8 hours) and during curcumin concentration $(50 \mu \mathrm{g} / \mu \mathrm{l})$ on IGF-2 gene was highly statistically significant changed between (32,56 and 64 hours) and (8 hours) show in (Figure 3 and Table 2). The effect of curcumin concentration $(25 \mu \mathrm{g} / \mu \mathrm{l})$ on BRCA1 gene was highly statistically significant changed between (24,32 and 40 hours) and ( 8 hours) and during curcumin concentration $(50 \mu \mathrm{g} / \mu \mathrm{l})$ on BRCA1gene was highly statistically significant changed between (16,24 and 32 hours) and (8 hours) show in (Figure 4 and Table 3 ) in vitro presence of various concentration of curcumin $(25-50 \mu \mathrm{g} / \mu \mathrm{l})$ indicated a significant increase of the down regulatin for (IGF1,IGF-2 and BRCA1) gene. The different concentration of curcumin(25$50 \mu \mathrm{g} / \mu \mathrm{l})$ and the different duration time $(0 \mathrm{~h}, 8 \mathrm{~h}, 16 \mathrm{~h}, 24 \mathrm{~h}, 32 \mathrm{~h}, 40 \mathrm{~h}, 48 \mathrm{~h}, 56 \mathrm{~h}$, $64 \mathrm{~h}$ and 72h) effect on inactivation of (IGF-1-IGF-2 and BRCA-1) genes.

Table 2: Effect of concentration of curcumin $(25-50 \mu \mathrm{g} / \mu \mathrm{l})$ on IGF-2 gene

\begin{tabular}{|l|c|c|}
\hline \multicolumn{3}{|c|}{ Concentration of curcumin $(25 \mu \mathrm{g} / \mu \mathrm{l})$ and $(50 \mu \mathrm{g} / \mu \mathrm{l})$ on IGF-2 gene } \\
\hline \multirow{2}{*}{ Hours } & $\begin{array}{c}\text { IGF-2 } \\
\text { At }(25 \mu \mathrm{g} / \mu \mathrm{l}) \text { curcumin }\end{array}$ & $\begin{array}{c}\text { IGF-2 } \\
\text { At }(50 \mu \mathrm{g} / \mu \mathrm{l}) \text { curcumin }\end{array}$ \\
\hline 0 & 0 & 0 \\
\hline 8 & $-0.63 \pm 0.23^{*}$ & $-1.73 \pm 0.63^{*}$ \\
\hline 16 & $-1.05 \pm 0.18^{*}$ & $-2.88 \pm 0.51^{*}$ \\
\hline 24 & $-1.98 \pm 1.11^{*}$ & $-3.79 \pm 1.42^{*}$ \\
\hline 32 & $-1.89 \pm 1.02^{*}$ & $-4.51 \pm 2.14^{* *}$ \\
\hline 40 & $-2.49 \pm 1.62^{*}$ & $-4.03 \pm 1.66^{*}$ \\
\hline 48 & $-2.91 \pm 2.04^{*}$ & $-4.39 \pm 2.02^{*}$ \\
\hline 56 & $-3.01 \pm 2.14^{*}$ & $-4.54 \pm 2.17^{* *}$ \\
\hline 64 & $-3.1 \pm 2.23^{*}$ & $-4.51 \pm 2.14^{* *}$ \\
\hline 72 & $-3.49 \pm 2.62^{* *}$ & $-4.33 \pm 1.96^{*}$ \\
\hline
\end{tabular}

*Significant at p-value $<0.05$

$* *$ Highly Significant at p-value $<0.001$ 


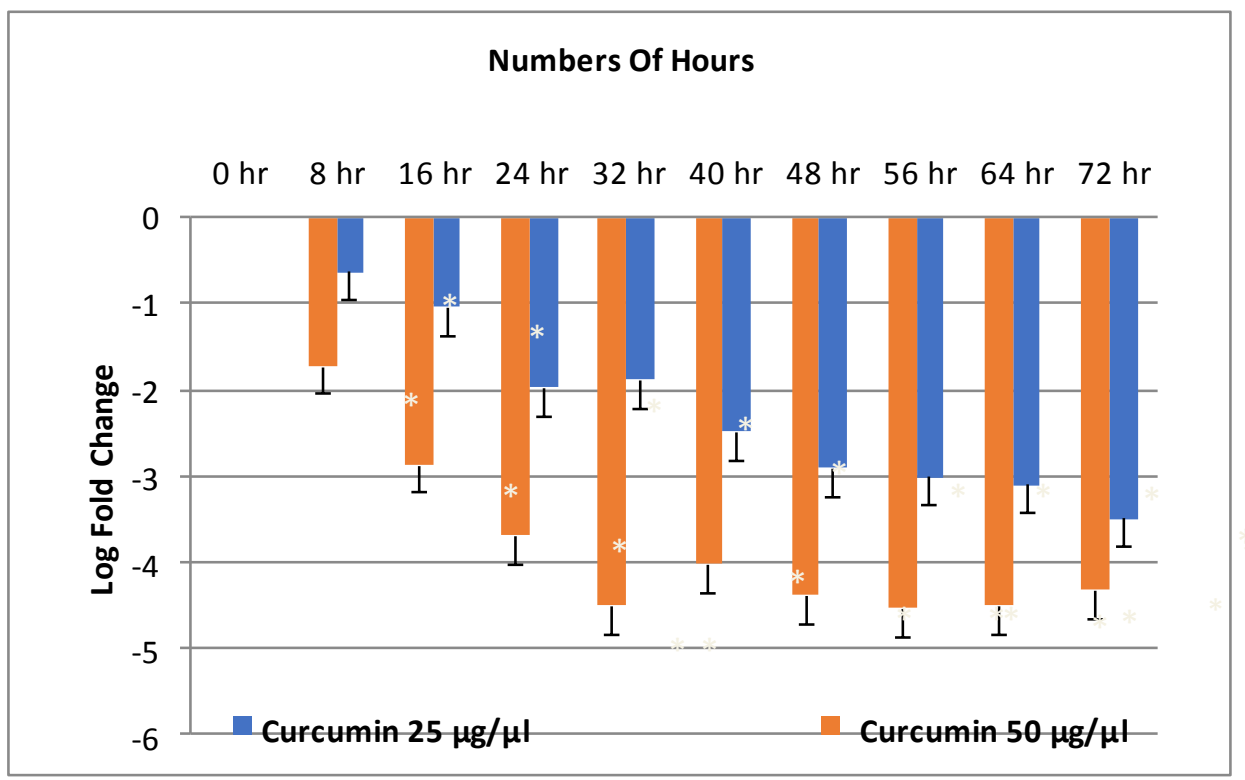

Figure 3: Multiple comparisons between the value of different concentrations of Curcumin $(25-50 \mu \mathrm{g} / \mu \mathrm{l})$ in IGF-2. Data represent the mean \pm standard error. The signs $(* * P<0.01, * P<0.05)$ denote significant differences from control and other treatment groups.

Results means, when we used different concentrations of curcumine (25$50 \mu \mathrm{g} / \mu \mathrm{l})$ for different duration time ( $0 \mathrm{~h}, 8 \mathrm{~h}, 16 \mathrm{~h}, 24 \mathrm{~h}, 32 \mathrm{~h}, 40 \mathrm{~h}, 48 \mathrm{~h}, 56 \mathrm{~h}, 64 \mathrm{~h}$ and $72 \mathrm{~h}$ ) on different genes related to breast cancer (IGF-1, IGF-2 and BRCA1), this is lead to down regulation for genes (IGF-1, IGF-2 and BRCA1) and this is the opposite of what supposed during cancer pathway, resulting in inactivation of genes (IGF-1,IGF-2 and BRCA1) and inactivation of genes may lead to stop the pathway of the breast cancer, and the cancer cycle not occur (Table 1 and Fig. 2). At curcumin concentration of $(50 \mu \mathrm{g} / \mu \mathrm{l})$, significant loss of activation of the gene than at concentration of $(25 \mu \mathrm{g} / \mu \mathrm{l})$ can be detected during the 0-72 hour's treatment period. The present experimental IGF-1 was down regulation and inactivation of IGF-1 in the presence of varying concentrations of curcumin $(25-50 \mu \mathrm{g} / \mu \mathrm{l})$ for different duration time and type of cell lines (MCF-7). These results are in agreement with the study of (Xia et al., 2007 and Choudhuri et al., 2002) he found that in the presence of various concentrations of curcumin for indicated time periods. Curcumin decreased the secretion of IGF-1 with a concomitant increase of IGFBP-3 in a dosedependent manner. results are also in agreement with the study of (Hosseini et 
al., 2019 and Sachdev and Yee, 2006 ) they proposed that the anti-metastatic effect of curcumin may mediate the downregulation of insulin and insulin-like growth factor-1 receptors, and showed that curcumin significantly decreased insulin and IGF-1 receptors.

The present results found also that IGF-2 gene was higher down regulation in the presence of concentrations of curcumin $(50 \mu \mathrm{g} / \mu \mathrm{l})$ for different times is significantly higher in that IGF-2 gene in the presence of concentrations of curcumin $(25 \mu \mathrm{g} / \mu \mathrm{l})$. Results are in agreement with the study of (Tian et al., 2017) he found that curcumin inhibits IGF2 expression in a dose- and time-dependent manner. results of the present study revealed that the curcumin with different concentrations treated different genes on MCF-7 cell lines resulted in significant inhibition of both IGF-1 and IGF-2 (Table 2 and Fig.3).

The present results are in agreement with the study of (Sun et al., 2012 and Lev-Ari et al., 2006) they showed that inhibition of cell survival and induction of apoptosis by curcumin in colorectal adenocarcinoma cell lines is associated with the inhibition of PGE2 synthesis and downregulation of COX-2.

The present results found also that BRCA1gene was higher down regulation in the presence of concentrations of curcumin $(50 \mu \mathrm{g} / \mu \mathrm{l})$ for different time is significantly higher in that in the presence of concentrations of curcumin $(25 \mu \mathrm{g} / \mu \mathrm{l})$. Our results demonstrate that BRCA1gene was down regulation in the presence of varying concentrations of curcumin $(25-50 \mu \mathrm{g} / \mu \mathrm{l})$ for different duration time and gene expression was measured by real time polymers chain reaction (PCR) .Results are in agreement with the study of (Rowe et al., 2009 ). They examined the effect of curcumin on BRCA1 in TNBCs. Total BRCA1 protein expression was induced in MDA468 and HCC1806 cells within $6 \mathrm{~h}$ of treatment with $10 \mu \mathrm{M}$ curcumin (Table 3 and Fig.4).

Conclusively, breast cancer is among the most common malignant tumors. It is the second leading cause of cancer mortality among women in the world. Curcumin, an active derivative from turmeric, has been investigated to have anticancer and chemoprevention effects on breast cancer.in this study different concentrations of curcumin influence the expression of gene targeting metabolism on breast cancer and make inactivation to it which may lead to stopping the breast cancer pathway. The present data demonstrated that curcumin could be used as the treatment of breast cancer. 
Table 3: Effect of concentration of curcumin $(25-50 \mu \mathrm{g} / \mu \mathrm{l})$ on BRCA1 gene Concentration of curcumin $(25 \mu \mathrm{g} / \mu \mathrm{l})$ and $(50 \mu \mathrm{g} / \mu \mathrm{l})$ on BRCA1 gene

\begin{tabular}{|l|c|c|}
\hline \multirow{2}{*}{ Hours } & BRCA1 & BRCA1 \\
& At $(25 \mu \mathrm{g} / \mu \mathrm{I})$ curcumin & At $(50 \mu \mathrm{g} / \mu \mathrm{\mu l})$ curcumin \\
\hline 0 & 0 & 0 \\
\hline 8 & $-1.5 \pm 0.54^{*}$ & $-1.92 \pm 0.70^{*}$ \\
\hline 16 & $-2.25 \pm 0.20^{*}$ & $-3.01 \pm 0.38^{* *}$ \\
\hline 24 & $-2.64 \pm 1.59^{* *}$ & $-3.19 \pm 0.56^{* *}$ \\
\hline 32 & $-2.88 \pm 0.83^{* *}$ & $-3.07 \pm 1.04^{* *}$ \\
\hline 40 & $-2.85 \pm 0.80^{* *}$ & $-2.67 \pm 0.04^{*}$ \\
\hline 48 & $-2.79 \pm 0.74^{*}$ & $-2.64 \pm 0.01^{*}$ \\
\hline 56 & $-2.64 \pm 0.59^{*}$ & $-2.79 \pm 0.16^{*}$ \\
\hline 64 & $-2.55 \pm 0.50^{*}$ & $-2.76 \pm 0.13^{*}$ \\
\hline 72 & $-2.52 \pm 0.47^{*}$ & $-2.58 \pm 0.04^{*}$ \\
\hline
\end{tabular}

*Significant at $\mathrm{P}$-value $<0.05 . \quad$ **Highly Significant at $\mathrm{p}$-value $<0.001$.

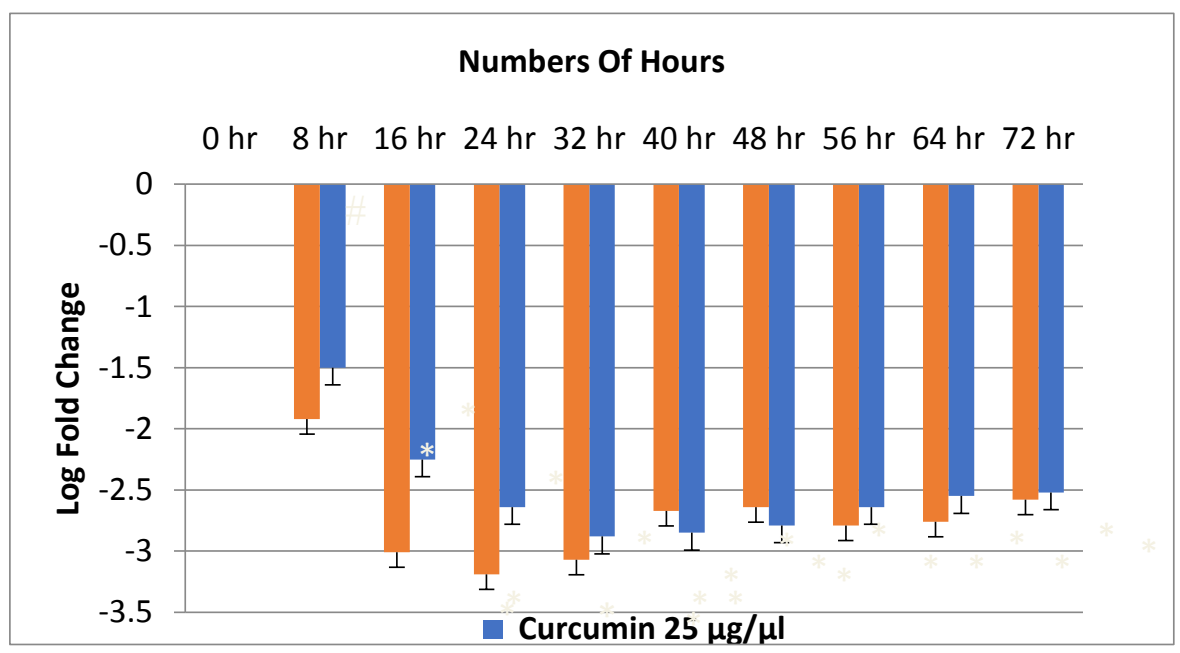

Figure 4: Multiple comparisons between the value of different concentrations of Curcumin $(25-50 \mu \mathrm{g} / \mu \mathrm{l})$ in BRCA1. Data represent the mean \pm standard error the signs $(* * P<0.01, * P<0.05)$ denote significant difference from control and other treatment groups.

\section{REFERENCES}

Aggarwal, B. B., Bhatt, I. D., Ichikawa, H., Ahn, K. S., Sethi, G., Sandur, S. K., ... \& Shishodia, S. (2006): 10 Curcumin-biological and medicinal properties. In book: Turmeric: The Genus Curcuma. Chapter: Curcumin, Biological And Medicinal Properties. Editors: P.N. Ravindran, K. Nirmal Babu, and K. Sivaraman. 
Bimonte, S., Barbieri, A., Palma, G., Rea, D., Luciano, A., D'Aiuto, M. and Izzo, F. (2015): Dissecting the role of curcumin in tumour growth and angiogenesis in mouse model of human breast cancer. Biomed Research International. DOI: 10.1155/2015/878134

Cao, J., Jia, L., Zhou, H. M., Liu, Y., \& Zhong, L. F. (2006): Mitochondrial and nuclear DNA damage induced by curcumin in human hepatoma G2 cells. Toxicological Sciences, 91(2), 476-483.

Choudhuri, T., Pal, S., Agwarwal, M. L., Das, T., \& Sa, G. (2002): Curcumin induces apoptosis in human breast cancer cells through p53dependent Bax induction. Febs Letters, 512(1-3): 334-340.

Downs, B., \& Wang, S. M. (2015): Epigenetic changes in BRCA1-mutated familial breast cancer. Cancer Genetics, 208(5): 237-240.

Gooch, J. L., Van Den Berg, C. L., \& Yee, D. (1999): Insulin-like growth factor (IGF)-I rescues breast cancer cells from chemotherapy-induced cell death-proliferative and anti-apoptotic effects. Breast cancer research and treatment, 56(1): 1-10.

Gupta, A. P., Pandotra, P., Sharma, R., Kushwaha, M., \& Gupta, S. (2013a). Marine resource: A promising future for anticancer drugs. In Studies in natural products chemistry (Vol. 40, pp. 229-325). Elsevier.

Gupta, S. C., Patchva, S., \& Aggarwal, B. B. (2013b). Therapeutic roles of curcumin: lessons learned from clinical trials. The AAPS Journal, 15(1): 195-218.

Hosseini, S. A., Zand, H., \& Cheraghpour, M. (2019): The influence of curcumin on the downregulation of MYC, insulin and IGF-1 receptors: a possible mechanism underlying the anti-growth and anti-migration in chemo resistant colorectal cancer cells. Medicina, 55(4), 90.

Lambrechts, S., Decloedt, J. \& Neven, P. (2011). Breast cancer prevention: lifestyle changes and chemoprevention. Acta Clinica Belgica, 66(4):283292.

Lev-Ari, S., Maimon, Y., Strier, L., Kazanov, D., \& Arber, N. (2006): Down-regulation of prostaglandin E2 by curcumin is correlated with inhibition of cell growth and induction of apoptosis in human colon carcinoma cell lines. Journal of the Society for Integrative Oncology, 4(1): 21-26.

Mirzaei, H., Shakeri, A., Rashidi, B., Jalili, A., Banikazemi, Z., \& Sahebkar, A. (2017): Phytosomal curcumin: A review of pharmacokinetic, experimental and clinical studies. Biomedicine \& Pharmacotherapy, 85:102-112. 
Mosmann, T. (1983): Rapid colorimetric assay for cellular growth and survival: application to proliferation and cytotoxicity assays. Journal of Immunological Methods, 65(1-2), 55-63.

Perrone, D., Ardito, F., Giannatempo, G., Dioguardi, M., Troiano, G., Lo Russo, L., ... \& Lo Muzio, L. (2015): Biological and therapeutic activities, and anticancer properties of curcumin. Experimental And Therapeutic Medicine, 10(5): 1615-1623.

Rao, X., Huang, X., Zhou, Z., and Lin, X. (2013): An improvement of the 2^ (-delta delta CT) method for quantitative real-time polymerase chain reaction data analysis. Biostatistics, Bioinformatics And Biomathematics, 3 (3): 71.

Renehan, A. G., Harvie, M., \& Howell, A. (2006): Insulin-like growth factor (IGF)-I, IGF binding protein-3, and breast cancer risk: eight years on Endocrine Related Cancer. Society for Endocrinology, 13(2): 273-278.

Richardson, A. E., Hamilton, N., Davis, W., Brito, C., \& De León, D. (2011): Insulin-like growth factor-2 (IGF-2) activates estrogen receptor- $\alpha$ and- $\beta$ via the IGF-1 and the insulin receptors in breast cancer cells. Growth Factors, 29(2-3), 82-93.

Roa M, Blane K and Zonneberg M (1985): One Way Analysis of Variance. Version IA PC-STAT, University of Georgia, Athens, USA.

Rowe, D. L., Ozbay, T., O'Regan, R. M., \& Nahta, R. (2009): Modulation of the BRCA1 protein and induction of apoptosis in triple negative breast cancer cell lines by the polyphenolic compound curcumin. Breast cancer: basic and clinical research, 3, BCBCR-S3067.

Rubin, R., \& Baserga, R. (1995): Insulin-like growth factor-I receptor. Its role in cell proliferation, apoptosis, and tumorigenicity. Laboratory investigation. J. Of Technical Methods And Pathology, 73(3), 311-31.

Sachdev, D., \& Yee, D. (2006): Inhibitors of insulin-like growth factor signaling: a therapeutic approach for breast cancer. Journal Of Mammary Gland Biology And Neoplasia, 11(1): 27-39.

Schernhammer, E. S., Holly, J. M., Pollak, M. N., \& Hankinson, S. E. (2005): Circulating levels of insulin-like growth factors, their binding proteins, and breast cancer risk. Cancer Epidemiology and Prevention Biomarkers, 14(3): 699-704.

Singletary, K., MacDonald, C., Wallig, M., \& Fisher, C. (1996): Inhibition of 7, 12-dimethylbenz [a] anthracene (DMBA)-induced mammary tumorigenesis and DMBA-DNA adduct formation by curcumin. Cancer Letters, 103(2), 137-141. 
Stewart, B. W., Bray, F., Forman, D., Ohgaki, H., Straif, K., Ullrich, A., \& Wild, C. P. (2016): Cancer prevention as part of precision medicine: 'plenty to be done'. Carcinogenesis, 37(1), 2-9.

Sun, K. W., Ma, Y. Y., Guan, T. P., Xia, Y. J., Shao, C. M., Chen, L. G., ... \& He, X. J. (2012): Oridonin induces apoptosis in gastric cancer through Apaf-1, cytochrome c and caspase-3 signaling pathway. World Journal of Gastroenterology: WJG, 18(48): 7166.

Sung, H., Ferlay, J., Siegel, R. L., Laversanne, M., Soerjomataram, I., Jemal, A., \& Bray, F. (2021): Global cancer statistics 2020: GLOBOCAN estimates of incidence and mortality worldwide for 36 cancers in 185 countries. CA: A Cancer Journal For Clinicians.

Tian, B., Zhao, Y., Liang, T., Ye, X., Li, Z., Yan, D., ... \& Li, Y. (2017): Curcumin inhibits urothelial tumor development by suppressing IGF2 and IGF2-mediated PI3K/AKT/mTOR signaling pathway. Journal Of Drug Targeting, 25(7): 626-636.

Tinelli, A., Malvasi, A., Leo, G., Vergara, D., Pisanò, M., Ciccarese, M., ... \& Lorusso, V. (2010): Hereditary ovarian cancers: from BRCA mutations to clinical management. A modern appraisal. Cancer and Metastasis Reviews, 29(2), 339-350.

Toden, S., \& Goel, A. (2017): The holy grail of curcumin and its efficacy in various diseases: is bioavailability truly a big concern?. Journal of Restorative Medicine, 6(1): 27.

Wang, Y., Yu, J., Cui, R., Lin, J., \& Ding, X. (2016): Curcumin in treating breast cancer: A review. Journal Of Laboratory Automation, 21(6): 723-31.

Xia, Y., Jin, L., Zhang, B., Xue, H., Li, Q., \& Xu, Y. (2007): The potentiation of curcumin on insulin-like growth factor-1 action in MCF-7 human breast carcinoma cells. Life Sciences, 80(23): 2161-2169.

Yang, X. R., Chang-Claude, J., Goode, E. L., Couch, F. J., Nevanlinna, H., Milne, R. L., \& Radice, P. (2011): Associations of breast cancer risk factors with tumor subtypes: a pooled analysis from the Breast Cancer Association Consortium studies. Journal of the National Cancer Institute, 103(3), 250-263.

Zhou, S., Zhang, S., Shen, H., Chen, W., Xu, H., Chen, X., \& Tang, J. (2017): Curcumin inhibits cancer progression through regulating expression of microRNAs. Tumor Biology, 39(2): 1010428317691680. 


\section{تأثير العلاج بالمنتجات الطبيعية على الجين المستهذفة لعملية الايض

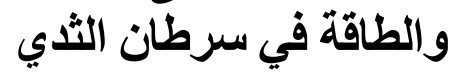

سلوى السيد محمد ${ }^{3}$ ، ميداء ناصر عشري ${ }^{2}$ ، خليل الحلفاوي ${ }^{3}$ ، وائل رشدي 4 ، ، وائل سعد عبد المجيد 5 1 البيولوجيا الجزيئية للخلية قسم البيولوجيد البيا الجزيئية ، معهد أبحاث الهندسة الور اثية و التكنولوجيا

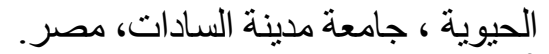

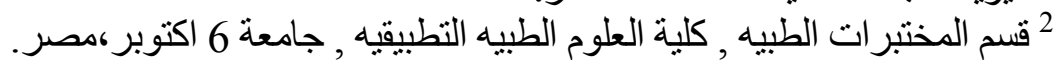

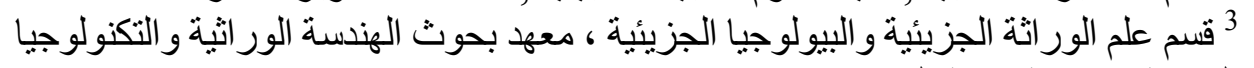

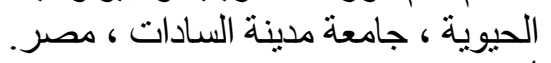

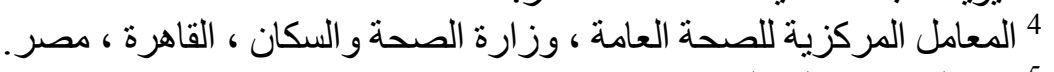
5 قسم الور اثة ، كلية الزراعة ، جامعة العة ، وزئ سويف ، مصر.

يعد سرطان الثذي من أكثر الأورام الخبيثة شيو عًا. وهو ثاني سبب رئيسي لوفيات السرطان

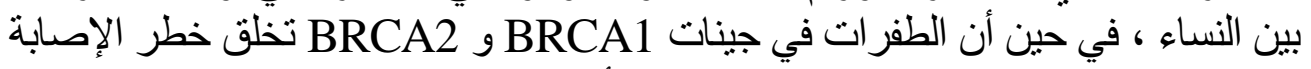

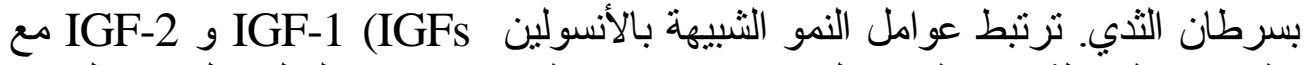

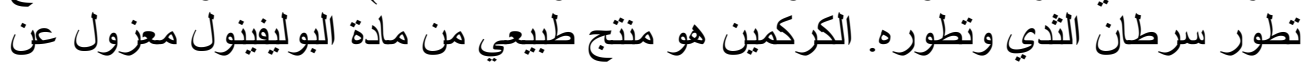

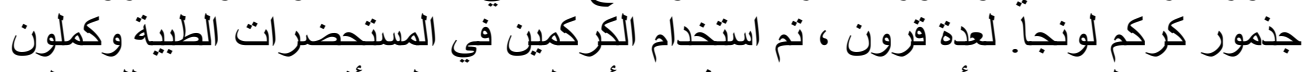

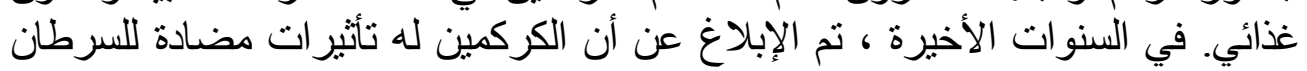

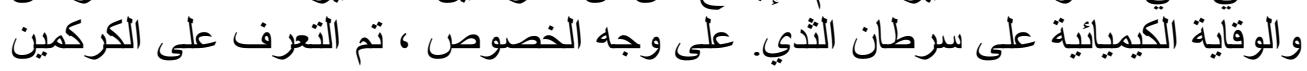

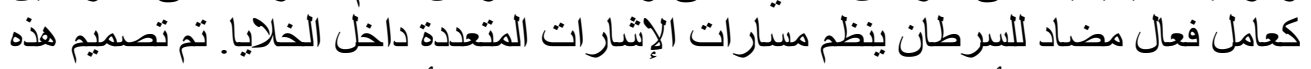

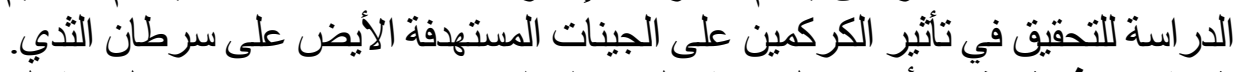

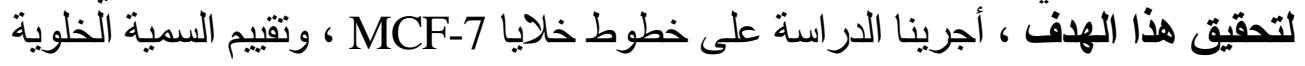

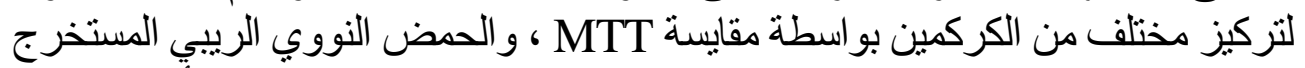

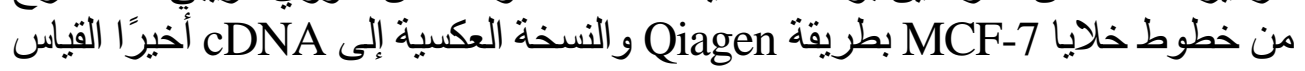

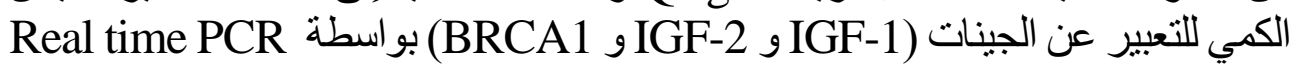
. (RT-PCR التوصية: أظهرت النتائج أن تركيز الكركمين الدختلف يؤدي إلى تثتيط الجينات المرتبطة

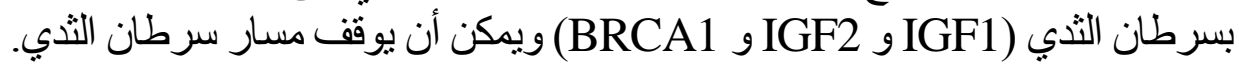

